\title{
Vitaindító: Miért és hogyan kellene a hazai népegészségügyet megújítani?
}

Debate: Why and how shoud we reform of our national public health?

Szerző: $\quad$ Vitrai József $\square$

Emberi erőforrások Minisztériuma

Beküldve: 2019. 04. 08.

doi: $\quad$ 10.24365/ef.v60i2.461

Összefoglaló: A szerző álláspontja szerint a hazai népegészségügy haladéktalanul megújításra szorul, mert - az Európai Unió országaihoz és különösen a Visegrádi országokhoz viszonyítva - a magyar lakosság egészségi mutatói egyre inkább lemaradást tükröznek. Ennek oka a szerző szerint az, hogy a szakma eddig nem volt képes kiharcolni az „Egészséget minden szakpolitikába” elv érvényre juttatását. A megújításhoz szükséges megerősíteni a hazai népegészségügyi szakma alapjait, és tevékenységeibe további tudományágak képviselőit bevonni. A megerősített és kiterjesztett szakmai alapokra támaszkodó népegészségügynek tisztáznia kellene, milyen legyen a jövő népegészségügye Magyarországon, és az hogyan kapcsolódjon az egészségügy és egyéb ágazatok szereplőihez.

Kulcsszavak: népegészségügy; megújítás

Summary: In the opinion of the author, national public health needs to be renewed immediately because the health indicators of the Hungarian population are increasingly lagging behind, compared to the countries of the European Union and especially the Visegrad countries. The reason for this, according to the author, is that the profession was not able to enforce the principle of "Health for All Policies". On the one hand, the foundations of the Hungarian public health should be strengthened for renewal, and on the other hand, representatives of other disciplines should be involved in public health activities. Public health relying on a strenghtened and extended professional basis should clarify the future of public health in Hungary, as well as its relations to health care and other sectors.

Keywords: public health; reform

\section{MIÉRT KELL MEGÚJITTANI?}

Számos hazai és nemzetközi dokumentumban szerepelt már az a megállapítás, hogy a magyar lakosság egészsége rosszabb annál, mint ami az ország társadalmi-gazdasági helyzetében elvárható lenne. Az elmaradás szembetűnő a legnagyobb terhet jelentő nem fertőző, krónikus betegségek terén, és közöttük kiemelkedően jelentős a daganatos, valamint a szív- és érrendszeri betegségekben. Nemzetközi tapasztalatok igazolják, hogy e betegségek eredményesen megelőzhetők az egészséges életmód előmozdításával és az egészséget támogató fizikai és társas környezet kialakításával, amelyek átfogó társadalmi, kulturális változások szükségességét feltételezik. Ezek kezdeményezésében és megvalósításának szakmai irányításában a modern népegészségügyé a vezető szerep mindenütt. A hazai egészségindikátorok értékei alapján azonban megállapítható, hogy a magyar népegészségügynek nem sikerült ilyen irányító pozícióba jutnia. A lakosság egészségében évtizedek óta fennálló relatív hátrány ledolgozásához éppen ezért a hazai népegészségügyben újfajta 
közpolitikai szerep felvállalása és sikeres „eljátszása" látszik szükségesnek.

\section{HOVÁ KELL ELUTNI?}

Az egészség védelme és fejlesztése össztársadalmi feladat, amit a nemzetközi szakdokumentumokban, fórumokon az egyes nemzetek egészségügyének már évek óta követésre ajánlott „Egészség minden szakpolitikában” (Health in all policy) elv foglal össze. Az elv magyarországi alkalmazásához nélkülözhetetlen az egészség társadalmi beágyazottságáról való ismeretek széleskörű elfogadtatása az egészségügyben, a közpolitikai döntéshozók és a lakosság körében. Ehhez el kell érni, hogy visszaszoruljon az a - hazai szakpolitikában ma elterjedt, korszerútlen - szemlélet, amely a gyógyítás mellett a megelőzést nem tartja egyenrangúan fontosnak, vagy ami eltúlozza az egyén felelősségét életmódjának megválasztásában.

A WHO Egészség2020 dokumentumai ezzel kapcsolatban így fogalmaz: „A mai egészségproblémákat nehéz megoldani, mert azok komplexek, összetettek, többszintűek és gyorsan változók. ... Sok XXI. századi egészségprobléma 'ördögi'. Tulajdonságaik alapján komplexek, és az okok és okozatok közötti kapcsolatok aligha lineárisak. Az 'ördögi' problémákat komplex, nyílt rendszerként szükséges elemezni."ii Ugyanitt, az elhízás visszaszorításával kapcsolatban megállapítják: „Csakis rendszerszintú megközelítés, a kormányzat különböző szintjein megvalósított többféle, az elhízás komplexitását és 'ördögi' természetét felismerő beavatkozások adnak esélyt visszaszorítására."

A hazai népegészségügynek ezt a szemléletváltást kell elsőrendű feladatának tekintenie: mindhárom célcsoport, vagyis az egészségügyi szakemberek, a közpolitikai döntéshozók és a lakosság felé egyidejúleg megfelelő kommunikációt, tudásbővítést kell megvalósítania. Az „Egészség minden szakpolitikában” elvre épülő közpolitika az egészségügy mellett természetesen más szektorok egészséget támogató aktivitását is feltételezi, ezért negyedik és ötödik célcsoportként egyéb területek szakemberei és döntéshozói azonosíthatók.
Mennyire felkészült a magyar népegészségügy, mennyire képes a modern népegészségügyi szemlélet képviseletére, ezáltal az egészség terén a lakosság érdekeinek képviseletére?

\section{MIN KELL ELŐSZÖR VÁLTOZTATNI?}

1. A hazai népegészségügy szakmai háttere „töredezett":

a. A kicsiny magyar népegészségügyi szakma három különálló szervezete és öt szaklapja jól jelzi az egység hiányát, azt, hogy a szakma mennyire "többszólamú”, mennyire eltérő szemlélet, meggyőződés vezeti képviselőit.

b. Inkoherens a hazai szakembereknek a népegészségügy feladatairól, intézményi struktúrájáról kialakított elképzelése. Részben ez az oka a jelenlegi szervezet múködési problémáinak, a fejlesztések sikertelenségének, és végső soron a népegészségügyi beavatkozások elmaradt eredményeinek.

2. Szegényesek a hazai népegészségügy „oldalirányú" kapcsolatai:

c. A tudomány területén a népegészségügyet a gyógyításfókuszú orvoslás képviseli, elszigetelve más tudományoktól, mint a pszichológia, szociológia, rendszertudomány, társadalomföldrajz stb.

d. A népegészségügyi tevékenység országos és helyi megvalósításába a köznevelésen kívül nemigen vonják be más szektorok szereplőit.

3. A hazai népegészségügy tevékenysége túlnyomóan az egyénekre irányul:

e. Az oktatás, a kutatás, a gyakorlat főként az egyén kockázatnak kitettségére, egészségmúveltségére fókuszál. Ezt a szemléletet tükrözik a jelenleg leghangsúlyosabb népegészségügyi témák: a rákszúrés, a dohányzásleszokás támogatása, oltások, különféle célú egyéni tanácsadások stb.

f. Az oktatásból, a kutatásból és a gyakorlatból hiányzik a komplexitás és az

\footnotetext{
Health 2020. A European policy framework and strategy for the 21st century. World Health Organization 2013. 58.0.

ii A komplex nyílt vagy alkalmazkodó rendszer elterjedt meghatározása: nagyszámú, különböző elem, több szinten kölcsönhatásba lép egymással, és ennek eredményeképpen az egyes elemek hatásaitól eltérő, új, gyakran megjósolhatatlan hatás jelenik meg, ami tartós lehet, sőt, a változó körülményekhez alkalmazkodik.
} 
egészségkultúra szemlélete, azaz a viselkedés és a környezeti kockázatok társadalmi-kulturális beágyazottsága, meghatározottsága.

\section{MIT KELL TENNI?}

A hazai népegészségügynek az „Egészség minden szakpolitikában" elv alkalmazásához szükséges szemléletváltás előmozdításához három területen kell mélyreható változást elérnie.

Egyrészt, megerősíteni a népegészségügy szakmai alapjait, komoly erőfeszítéseket tenni a népegészségügyi oktatás és kutatás területén a korszerú ismeretek, megközelítések, gyakorlatok elterjesztése érdekében:

a) széleskörű összefogással kidolgozni a változtatás koncepcióját, és azt szakmai fórumokon megvitatni, elfogadtatni;

b) a magyarországi népegészségügyi tudás koncentrálásához összevonni a népegészségügy szakmai szervezeteit és azok fórumait;

c) az erőforrások hatékony felhasználásához országosan összehangolni az oktatást, továbbképzést, valamint a kutatást.
Másrészt, más tudományágak bevonásával a népegészségügy szélesebb szakmai alapokra helyezése elengedhetetlen, ehhez szükséges:

d) kiterjeszteni a népegészségügy tudományos bázisát, bevonni más tudományágak képviselőit, kiemelten a szociológia, a kulturális antropológia, a pszichológia, a politikatudomány, múszaki tudományok és a rendszertudományok egyes területeiről;

e) az így létrejövő multidiszciplináris munkacsoportoknak, kutatóműhelyeknek - teljesítményük független minősítésének érdekében belépniük a nemzetközi tudományos szintérre, melyhez a támogatást intézményeik, valamint hazai kutatási pályázatok biztosíthatják.

Ezt követően, a megerősített és kiterjesztett szakmai alapokra támaszkodva tisztázni lehet mind a szakmán belül, mind az egészségügyi szakpolitika számára, hogy

f) milyen népegészségügyi rendszert lenne célszerú létrehozni Magyarországon, és az milyen szervezeti struktúrában, milyen irányítással és finanszírozással múködjön;

g) hogyan kell a népegészségügynek kapcsolódnia az egészségügyi rendszer más elemeihez, például az alap- és szakellátáshoz, valamint milyen interszektoriális kapcsolatokat kell kiépítenie. 